\title{
KEKUATAN AKTA AUTENTIK YANG DIBUAT OLEH NOTARIS UNTUK PEMBUKTIAN TERHADAP TINDAK PIDANA PEMALSUAN
}

\author{
Sony Nurul Akhmad \\ Magister Kenotariatan \\ Universitas Islam Malang \\ Email : misranto.fh@gmail.com \\ Sony Nurul Akhmad \\ Magister Kenotariatan \\ Program Pascasarjana Universitas Islam Malang \\ Email : sony_akhmad@ymail.com
}

\begin{abstract}
Abstrak
Akta autentik merupakan akta yang dibuat oleh pejabat umum yang berwenang yang memuat atau menguraikan secara otentik sesuatu tindakan yang dilakukan atau suatu keadaan yang dilihat atau disaksikan oleh pejabat umum pembuat akta itu. Kedudukan akta otentik yang dikeluarkan atau dibuat oleh notaris mempunyai kekuatan hukum yang mengandung kepastian hukum terhadap pembuktian tindak pidana pemalsuan. Dalam hal alat bukti, akta otentik yang dikeluarkan notaris ini berkedudukan sebagai alat bukti surat. Jika akta otentiknya dipalsukan, maka ia dapat menjadi salah satu alat bukti yang bisa digunakan menjerat (mempertanggunjawabkan) pelakunya. Jika notarisnya terlibat dalam hal terjadinya tindak pidana pemalsuan akta, maka notaris ini juga dapat dijerat dengan pertanggungjawaban sebagai pihak yang melakukan pelanggaran hukum.
\end{abstract}

Kata kunci :akta autentik, pembuktian, pemalsuan.

\section{Abstract}

An authentic deed is a deed made by an authorized general official that contains or describes in an authentic manner an action or a situation that is seen or witnessed by the general official of the deed. The position of an authentic deed issued or made by a notary has legal force that contains legal certainty against proof of fraud. In the case of evidence, an authentic deed issued by a notary is located as proof of letter. If the authentic deed is falsified, then it is one proof that can be used to ensnare the responsible person. If the notary is involved in the case of a criminal act of falsification of the deed, then this notary may also be charged with liability as the party who committed a violation of the law.

Keywords: authentic deed, proof, falsificatio 


\section{PENDAHULUAN}

Seseorang dapat melakukan kejahatan atau tindak pidana pemalsuan karena pengaruh keadaan yang dipandang buruk, tidak menguntungkan dirinya, sehingga cara-cara kriminal terpaksa dilakukannya, atau sehubungan dengan pengaruh kesulitan ekonomi yang menimpanya, maka cara yang melanggar hukum harus dilakukannya, karena cara-cara yang lain dianggap tidak ada lagi. Bisa pula tindak pidana terjadi disebabkan, bahwa seseorang berbuat jahat karena ingin kaya dengan cara yang gampang, atau kebutuhan ekonominya jauh lebih banyak dibandingkan kebutuhan pokoknya, sehingga menuntut dan memaksanya untuk memenuhi dengan cara yang salah (jahat).

Tindak pidana pemalsuan yang dilakukan seseorang atau sekelompok orang yang melibatkan atau berkaitan dengan kewenangan notaris adalah berkaitan dengan akte autentik, yang akte ini bisa saja dipalsukan, berisi keterangan yang tidak benar, atau aktenya sudah benar, tetapi dipalsukan, atau adanya keadaan, kejadian, atau perbuatan yang berkategori pelanggaran hukum pidana.

Tidak jarang terjadi, akta yang dibuat oleh notaris diikutkan oleh aparat penegak hukum dalam rangka pembuktian terhadap perkara tindak pidana pemalsuan, khususnya untuk menemukan kebenaran terhadap tindak pidana yang terjadi ini, benarkah kasus yang terjadi adalah pemalsuan.

Akta merupakan surat sebagai alat bukti yang diberi tanda tangan, yang memuat peristiwa yang menjadi dasar suatu hak atau perikatan, yang dibuat sejak semula dengansengaja untuk pembuktian. Keharusan adanya tanda tangan bertujuan untuk membedakan akta yang satu dengan akta yang lain atau dari akta yang dibuat orang lain. Fungsi tanda tangan adalah untuk memberi ciri atau mengindividualisir sebuah akta. ${ }^{1}$

Ada akta yang disebut sebagai akta di bawah tangan. Sedangkan pendapat lain menyebut ada akta otentik. Akta Di bawah Tangan adalah akta yang dibuat tidak di hadapan pejabat yang berwenang atau Notaris.Akta ini yang dibuat dan ditandatangani oleh para pihak yang membuatnya. Apabila suatu akta di bawah tangan tidak disangkal oleh Para Pihak, maka berarti mereka mengakui dan tidak menyangkal kebenaran apa yang tertulis pada akta di bawah tangan tersebut, sehingga sesuai pasal 1857 KUH Perdata akta di bawah tangan tersebut memperoleh kekuatan pembuktian yang sama dengan suatu Akta Otentik.

${ }^{1}$ Sudikno Mertokusumo, Hukum Acara Perdata Indonesia. (Yogyakarta: Liberty, 1998), hal.142-143 
Adapunakta autentik ialah akta yang dibuat oleh pejabat umum yang berwenang yang memuat atau menguraikan secara otentik sesuatu tindakan yang dilakukan atau suatu keadaan yang dilihat atau disaksikan oleh pejabat umum pembuat akta itu. Pejabat umum yang dimaksud adalah notaris, hakim, juru sita pada suatu pengadilan, pegawai pencatatan sipil, dan sebagainya.

Suatu akta otentik mempunyai kekuatan pembuktian yang sempurna bagi para pihak beserta seluruh ahli warisnya atau pihak lain yang mendapat hak dari para pihak. Sehingga apabila suatu pihak mengajukan suatu akta autentik, hakim harus menerimanya dan menganggap apa yang dituliskan di dalam akta itu sungguh-sungguh terjadi, sehingga hakim itu tidak boleh memerintahkan penambahan pembuktian lagi.

Pembuktian dengan tulisan dilakukan dengan tulisan otentik atau dengan tulisan di bawah tangan.(vide pasal 1867 Kitab Undang-Undang Hukum Perdata ("KUHPerdata")) Akta autentik adalah akta yang dibuat dan dipersiapkan oleh notarisatau pejabat resmi lainnya (misalnya Camat selaku Pejabat Pembuat Akta Tanah) untuk kepentingan pihak-pihak dalam kontrak.

Pembahasan tentang tindak pidana dapat dipelajari dalam KUHP. Sebagaimana diatur dalam Pasal 263 Kitab Undang Undang Hukum Pidana ("KUHP") yang berbunyi:

(1) Barang siapa membuat surat palsu atau memalsukan surat yang dapat menimbulkan sesuatu hak, perikatan atau pembebasan hutang, atau yang diperuntukkan sebagai bukti daripada sesuatu hal dengan maksud untuk memakai atau menyuruh orang lain memakai surat tersebut seolah-olah isinya benar dan tidak dipalsu, diancam jika pemakaian tersebut dapat menimbulkan kerugian, karena pemalsuan surat, dengan pidana penjara paling lama enam tahun.

(2) Diancam dengan pidana yang sama, barang siapa dengan sengaja memakai surat palsu atau yang dipalsukan seolah-olah sejati, jika pemakaian surat itu dapat menimbulkan kerugian.

Selanjutnya, di dalam Pasal 264 KUHP ditegaskan bahwa:

(1) Pemalsuan surat diancam dengan pidana penjara paling lama delapan tahun, jika dilakukan terhadap:

1. akta-akta otentik;

2. surat hutang atau sertifikat hutang dari sesuatu negara atau bagiannya ataupun dari suatu lembaga umum;

3. surat sero atau hutang atau sertifikat sero atau hutang dari suatu perkumpulan, yayasan, perseroan atau maskapai:

4. talon, tanda bukti dividen atau bunga dari salah satu surat yang diterangkan dalam 2 dan 3, atau tanda bukti yang dikeluarkan 
sebagai pengganti surat-surat itu;

5. surat kredit atau surat dagang yang diperuntukkan untuk diedarkan;

(2) Diancam dengan pidana yang sama barang siapa dengan sengaja memakai surat tersebut dalam ayat pertama, yang isinya tidak sejati atau yang dipalsukanseolah-olah benar dan tidak dipalsu, jika pemalsuan surat itu dapat menimbulkan kerugian.

Di dalam bukunya Kitab Undang-undang Hukum Pidana (KUHP) Serta Komentar-Komentarnya Lengkap Pasal Demi Pasal ${ }^{2}$ mengatakan bahwa yang diartikan dengan surat dalam bab ini adalah segala surat, baik yang ditulis dengan tangan, dicetak, maupun ditulis memakai mesin ketik, dan lain-lainnya.

Surat yang dipalsukan itu harus surat yang:

1. dapat menimbulkan sesuatu hak (misalnya: ijazah, karcis tanda masuk, surat andil, dan lain-lain);

2. dapat menerbitkan suatu perjanjian (misalnya surat perjanjian piutang, perjanjian jual beli, perjanjian sewa, dan sebagainya);

3. dapat menerbitkan suatu pembebasan hutang (kuitansi atau surat semacam itu); atau

4. surat yang digunakan sebagai keterangan bagi suatu perbuatan atau peristiwa (misalnya surat tanda kelahiran, buku tabungan pos, buku kas, buku harian kapal, surat angkutan, obligasi, dan lain-lain).

Adapun bentuk-bentuk pemalsuan surat itu menurut Soesilo dilakukan dengan cara:

1. membuat surat palsu: membuat isinya bukan semestinya (tidak benar).

2. memalsu surat: mengubah surat sedemikian rupa sehingga isinya menjadi lain dari isi yang asli. Caranya bermacam-macam, tidak senantiasa surat itu diganti dengan yang lain, dapat pula dengan cara mengurangkan, menambah atau merubah sesuatu dari surat itu.

3. memalsu tanda tangan juga termasuk pengertian memalsu surat.

4. penempelan foto orang lain dari pemegang yang berhak (misalnya foto dalam ijazah sekolah).

Unsur-unsur pidana dari tindak pidana pemalsuan surat selain yang disebut di atas adalah: ${ }^{3}$

1. pada waktu memalsukan surat itu harus dengan maksud akan menggunakan atau menyuruh orang lain menggunakan surat itu seolah-olah asli dan tidak dipalsukan;

${ }^{2}$ R. Soesilo. Kitab Undang-undang Hukum Pidana (KUHP) Serta KomentarKomentarnya Lengkap Pasal Demi Pasal, (Bogor, Politeia, 1991), hal. 195.

${ }^{3}$ Ibid, hal. 196. 
2. penggunaannya harus dapat mendatangkan kerugian. Kata "dapat" maksudnya tidak perlu kerugian itu betul-betul ada, baru kemungkinan saja akan adanya kerugian itu sudah cukup;

3. yang dihukum menurut pasal ini tidak saja yang memalsukan, tetapi juga sengaja menggunakan surat palsu. Sengaja maksudnya bahwa orang yang menggunakan itu harus mengetahui benar-benar bahwa surat yang ia gunakan itu palsu. Jika ia tidak tahu akan hal itu, ia tidak dihukum. Suda dianggap "mempergunakan" misalnya menyerahkan surat itu kepada orang lain yang harus mempergunakan lebih lanjut atau menyerahkan surat itu di tempat dimana surat tersebut harus dibutuhkan.

4. Dalam hal menggunakan surat palsu harus pula dibuktikan bahwa orang itu bertindak seolah-olah surat itu asli dan tidak dipalsukan, demikian pula perbuatan itu harus dapat mendatangkan kerugian

Pengertian notaris menurut Undang Undang Nomor 30 tahun 2004 sudah disebut dalam pasal 1 bahwa "notaris adalah pejabat umum yang berwenang untuk membuat akta otentik dan kewenangan lainnya sebagaimana maksud dalam undang-undang ini."

Dalam Pasal 1 angka 1 Undang-Undang Republik Indonesia Nomor 2 Tahun 2014 Tentang Perubahan Atas Undang-Undang Nomor 30 Tahun 2004 Tentang Jabatan Notaris disebutkan, bahwa Notaris adalah pejabat umum yang berwenang untuk membuat akta autentik dan memiliki kewenangan lainnya sebagaimana dimaksud dalam UndangUndang ini atau berdasarkan undang-undang lainnya.

Perbedaan pengertian notaris di Undang-Undang Republik Indonesia Nomor 2 Tahun 2014 dan Undang-Undang Nomor 30 Tahun 2004 Tentang Jabatan Notaris terletak pada kewenangan notaris yang disebut dalam Undang-undang lainnya. Artinya notaris dalam Undang-Undang Nomor 30 Tahun 2004 hanya disebut dalam Undang-Undang Nomor 30 Tahun 2004 ini, sementara dalam Undang-Undang Republik Indonesia Nomor 2 Tahun 2014 disebut kalau notaris mempunyai kewenangan lain juga (sebagaimana disebutkan dalam Undang-undang lainnya).

Istilah pejabat umum melekat dalam dua produk yuridis itu (Undang-Undang Nomor 2 Tahun 2014 dan Undang-Undang Nomor 30 Tahun 2004 Tentang Jabatan Notaris).Pejabat umum sendiri adalah orang yang menjalankan sebagian fungsi publik dari negara, khususnya di bidang hukum perdata. Pejabat umum adalah seseorang yang diangkat dan diberhentikan oleh pemerintah dan diberi wewenang dan kewajiban untuk melayani publik dalam hal-hal tertentu karena ia ikut serta melaksanakan suatu kekuasaan yang bersumber pada kewibawaan dari pemerintah. Dalam 
jabatannya tersimpul suatu sifat atau ciri khas yang membedakannya dan jabatan-jabatan lainnya dalam masyarakat Indonesia.

Sebagai pejabat umum, notaris diangkat oleh Menteri untuk melaksanakan sebagian fungsi publik dari negara dan bekerja untuk pelayanan kepentingan umum khususnya dalam bidang hukum perdata, walaupun Notaris bukan merupakan pegawai negeri yang menerima gaji dari negara.Pelayanan kepentingan umum tersebut adalah dalam arti bidang pelayanan pembuatan akta dan tugas-tugas lain yang dibebankan kepada notaris, yang melekat pada predikat sebagai pejabat umum dalam ruang lingkup tugas dan kewenangan notaris.

Soal akta itu, Soegondo Notodisoerjo, menyatakan, bahwa untuk dapat membuat akta otentik, seseorang harus mempunyai kedudukan sebagai "penjabat umum". Di Indonesia, seorang advokat, meskipun ia seorang ahli dalam bidang hukum, tidak berwenang untuk membuat akta otentik, karena ia tidak mempunyai kedudukan sebagai "penjabat umum". Sebaliknya seorang "Pegawai Catatan Sipil" (Ambtenaar van de Burgerlijke Stand) meskipun ia bukan ahli hukum, ia berhak membuat akta-akta otentik untuk hal-hal tertentu, umpamanya untuk membuat akta kelahiran, akta perkawinan, akta kematian. Demikian itu karena ia oleh Undang-undang ditetapkan sebagai "pejabat umum" dan diberi wewenang untuk membuat akta-akta itu. ${ }^{4}$

Akta notaris yang diterbitkan oleh notaris memberikan kepastian hukum bagi masyarakat. Menurut Nusyirwan, notaris adalah orang semi swasta, karena ia tidak bisa bertindak bebas sebagaimana seorang swasta. Ia harus menjunjung tinggi martabatnya, oleh karena itu ia diperkenankan (diberi hak) menerima uang jasa (honorarium) untuk setiap pelayanan yang diberikannya. $^{5}$

\section{METODE PENELITIAN}

Penulis menggunakan jenis penelitian bersifat deskriptif.Suatu penelitian deskriptif ini dimaksudkan untuk memberikan data yang seteliti mungkin tentang manusia, keadaan atau gejala-gejala lainya. ${ }^{6}$ Penelitian ini diharapkan dapat memberikan gambaran awal untuk penelitian yang lebih lanjut (eksploratif) tentang bagaimanakedudukan akta autentik yang dibuat oleh notaris dalam kaitannya dengan tindak pidana pemalsuan.

\footnotetext{
${ }^{4}$ Kartini Soedjendro, Perjanjian Peraihan Hak atas Tanah yang Berpotensi Konflik, (Yogyakarta: Kanisius, 2001), hal. 43.

${ }^{5}$ Nusyirwan, Membedah Profesi Notaris, )Bandung: Universitas Padjadjaran, 2000), hal 3-4

${ }^{6}$ Soerjono Soekanto, Pengantar Penelitian Hukum, (Jakarta: Sinar Grafika, 1986), hal. 9
} 
Berdasarkan bahan hukum yang digunakan dalam penelitian, maka penelitian hukum ini menggunakan pendekatan peraturan perundangundangan dan konsepsional. Penelitian hukum dengan pendekatan peraturan perundang-undangan ini dilakukan dengan cara meneliti bahan pustaka atau data sekunder.

Penelitian hukum ini dapat juga dinamakan penelitian hukum kepustakaan. ${ }^{7}$ Studi kepustakaan atau kajian dari bahan-bahan pustaka ini terfokus pada masalah tentang bagaimana kedudukan akta autentik yang dibuat oleh notaris dalam kaitannya dengan pembuktian tindak pidana pemalsuan. Pada penelitian hukum yuridis normatif atau penelitian hukum kepustakaan, bahan pustaka merupakan data dasar yang dalam (ilmu) penelitian digolongkan sebagai data sekunder

Penelitian hukum ini dikatagorikan sebagai penelitian hukum yuridis normatif atau bisa juga disebut dengan penelitian hukum kepustakaan, maka untuk memperoleh data atau bahan hukum, penulis menggunakan teknik pengumpulan bahan hukum tentang kedudukan akta autentik dalam sistem pembuktian sebagaimana diatur dalam peraturan perundang-undangan dan bagaimana kedudukan akta autentik yang dibuat oleh notaris dalam kaitannya dengan tindak pidana pemalsuan.

Dalam penelitian ini, teknik content analisis yang digunakan secara deskriptif, artinya dengan menggunakan teknik analisa data atau bahan hukum secara deskriptif diharapkan dapat memperoleh paparan informasi tentang suatu gejala, peristiwa, kejadian sebagaimana adanya. Sedangkan analisisnya tertuju pada bagaimana kedudukan akta autentik dalam system pembuktian sebagaimana diatur dalam peraturan perundang-undangan dan bagaimana kedudukan akta autentik yang dibuat oleh notaris dalam kaitannya dengan pembuktian tindak pidana pemalsuan.

\section{PEMBAHASAN}

\section{Kedudukan Hukum Akta Otentik}

Arti sesungguhnya dari akta otentik adalah: akta-akta tersebut harus selalu dianggap benar, kecuali jika dibuktikan sebaliknya di muka pengadilan. Mengenai pemahaman dari akta otentik dituangkan dalam pasal 1868 Kitab Undang-Undang Hukum Perdata, yang mengatakan bahwa: "akta autentik adalah akta yang (dibuat) dalam bentuk yang ditentukan oleh undang-undang, dibuat oleh atau di hadapan pegawai-pegawai umum yang berkuasa untuk itu, ditempat dimana akta dibuatnya."

Ada tiga macam kekuatan akta autentik:

${ }^{7}$ Soerjono Soekanto \& Sri Mamudji, Penelitian Hukum Normatf, (Jakarta: Rajagrafindo Persada, 2003), hal. 13-14. 
1. Membuktikan antara para pihak, bahwa mereka sudah menerangkan apa yang ditulis dalam akte tadi (kekuatan pembuktian formil);

2. Membuktikan antara para pihak yang bersangkutan, bahwa sungguhsungguh peristiwa yang disebutkan disitu telah terjadi (kekuatan pembuktian materiel atau yang dinamakan kekuatan pembuktian mengikat);

3. Membuktikan tidak saja antara para pihak yang bersangkutan tetapi juga terhadap pihak ketiga, bahwa pada tanggal tersebut dalam akte ke dua belah

pihak tersebut sudah menghadap di muka pegawai umum (notaris) dan menerangkan apa yang ditulis dalam akte tersebut. ${ }^{8}$

Berdasarkan Pasal 1868 Kitab Undang-undang Hukum Perdata dapat disimpulkan unsur dari akta otentik, yaitu:

(1) akta tersebut dibuat dan diresmikan dalam bentuk menurut hukum,

(2) akta tersebut dibuat oleh atau di hadapan pejabat umum dan

(3) akta tersebut dibuat oleh atau di hadapan pejabat yang berwenang untuk membuatnya ditempat akta tersebut dibuat. ${ }^{9}$

Menurut 1868 KUHPerdata, bahwa suatu surat yang dibuat secara demikian oleh atau di hadapan pegawai umum yang berwenang membuatnya, menjadikan bukti yang cukup bagi kedua belah pihak dan ahli warisnya dan sekalian orang yang mendapatkan hak dari padanya, yaitu tentang segala hal, yang tersebut di dalam surat itu sebagai pemberitahuan saja, tetapi yang tersebut kemudian itu hanya sekedar yang diberitahukan kemudian itu langsung berhubungan dengan pokok dalam akta itu.

Akta autentik menurut Pasal 285 Rbg: yaitu yang dibuat, dengan bentuk yang sesuai dengan undang-undang oleh atau di hadapan pejabat umum yang berwenang di tempat akta itu dibuat, merupakan bukti lengkap antara para pihak serta keturunannya dan mereka yang mendapatkan hak tentang apa yang dimuat di dalamnya dan bahkan tentang suatu pernyataan belaka; hal terakhir ini sepanjang pernyataan itu ada hubungan langsung dengan apa yang menjadi pokok akta itu.

Akta mempunyai dua fungsi : fungsi formil (formalitas causa) dan fungsi alat bukti (probationis causa). Formalitas Causa artinya akta berfungsi untuk lengkapnya atau sempurnanya suatu perbuatan hukum, jadi bukan sahnya perbuatan hukum.Dalam konteks ini akta merupakan syarat

${ }^{8}$ Arief Rachman, Akte Otentik Dalam Hukum Positip Indonesia, https://notarisarief.wordpress.com/2011/05/15/akta-otentik-dalam-hukum-positifindonesia/, akses 15 Oktober 2018.

${ }^{9}$ Anshori, Lembaga Kenotariatan Indonesia Perspektif Hukum dan Etika, (Yogyakarta: UII Press, 2009), hal,18. 
formil untuk adanya suatu perbuatan hukum.Probationis causa berarti akta mempunyai fungsi sebagai alat bukti, karena sejak awal akta tersebut dibuat dengan sengaja untuk pembuktian dikemudian hari.Sifat tertulisnya suatu perjanjian dalam bentuk akta ini tidak membuat sahnya perjanjian tetapi hanyalah agar dapat digunakan sebagai alat bukti dikemudian hari.

Kekuatan pembuktian akta ini dibedakan menjadi tiga macam :

1) Kekuatan pembuktian lahir (kekuatan pembuktian yang didasarkan pada keadaan lahir, apa yang tampak pada lahirnya; acta publica probant sese ipsa);

2) Kekuatan pembuktian formil (memberikan kepastian tentang peristiwa bahwa pejabat dan para pihak menyatakan dan melakukan apa yag dimuat dalam akta);

3) Kekuatan pembuktian materiiil (memberikan kepastian tentang materi suatu akta).

Pasal 1888 menyebut.Bahwa kekuatan pembuktian dengan suatu tulisan terletak pada akta aslinya.Bila akta yang asli ada, maka salinan serta kutipan hanyalah dapat dipercaya sepanjang salinan serta kutipan itu sesuai dengan aslinya yang senantiasa dapat diperintahkan untuk ditunjukkan. Pasal 1889 menyebut, bahwa Bbila tanda alas hak yang asli yang sudah tidak ada lagi, maka salinannya memberikan bukti, dengan ketentuanketentuan sebagai berikut:

1. Salinan pertama (gross) memberikan bukti yang sama dengan akta asli; demikian pula halnya salinan yang dibuat atas perintah Hakim di hadapan kedua belah pihak atau setelah kedua pihak ini dipanggil secara sah sebagaimana juga yang salinan dibuat di hadapan kedua belah pihak dengan persetujuan mereka;

2. Salinan yang dibuat sesudah pengeluaran salinan pertama tanpa perantaraan Hakim atau tanpa persetujuan kedua belah pihak entah oleh Notaris yang di hadapannya akta itu dibuat, atau oleh seorang penggantinya ataupun oleh pegawai yang karena jabatannya menyimpan akta asli (minut) dan berwenang untuk memberikan salinan-salinan, dapat diterima Hakim sebagai bukti sempurna bila akta asli telah hilang;

3. Bila salinan yang dibuat menurut akta asli itu tidak dibuat oleh Notaris yang dihadapannya akta itu telah dibuat, atau oleh seorang penggantinya, atau oleh pegawai umum yang karena jabatannya menyimpan akta asli, maka salinan itu sama sekali tidak dapat dipakai sebagai bukti, melainkan hanya sebagai bukti permulaan tertulis; 
4. Salinan otentik dari salinan otentik atau dari akta di bawah tangan, menurut keadaan, dapat memberikan suatu bukti permulaan tertulis. ${ }^{10}$

Tabel 1: Perbedaan akta otentik dengan akta di bawah tangan ${ }^{11}$

\begin{tabular}{|c|c|c|}
\hline KETERANGAN & AKTA OTENTIK & $\begin{array}{l}\text { AKTA BAWAH } \\
\text { TANGAN }\end{array}$ \\
\hline \multicolumn{3}{|c|}{$\begin{array}{l}\text { Perbedaan pokok antara akta otentik dengan akta di bawah tangan } \\
\text { adalah cara pembuatan atau terjadinya akta tersebut. }\end{array}$} \\
\hline Definisi & $\begin{array}{l}\text { Suatu akta otentik ialah suatu } \\
\text { akta yang dibuat dalam } \\
\text { bentuk yang ditentukan } \\
\text { undang-undang oleh atau } \\
\text { dihadapan pejabat umum } \\
\text { yang berwenang untuk itu } \\
\text { (seperti Notaris, Hakim, } \\
\text { Panitera, Juru Sita, Pegawai } \\
\text { Pencatat Sipil), di tempat akta } \\
\text { itu dibuat.(vide Pasal } 1868 \\
\text { KUHPerdata, Pasal 165 } \\
\text { Herziene Indonesisch } \\
\text { Reglemen ("HIR"), dan Pasal } \\
\text { 285 Rechtsreglement } \\
\text { Buitengewesten ("RBg"). }\end{array}$ & $\begin{array}{l}\text { akta yang sengaja di } \\
\text { buat untuk pembuktian } \\
\text { oleh para pihak tanpa } \\
\text { bantuan dari seorang } \\
\text { pejabat. } \\
\text { cara pembuatan atau } \\
\text { terjadinya tidak } \\
\text { dilakukan oleh dan atau } \\
\text { dihadapan pejabat } \\
\text { pegawai umum, tetapi } \\
\text { cukup oleh pihak yang } \\
\text { berkepentingan saja } \\
\text { (vide Pasal 1874 } \\
\text { KUHPerdata dan Pasal } \\
\text { 286 RBg). }\end{array}$ \\
\hline
\end{tabular}

${ }^{10}$ Arief Rachman, Op.Cit.

${ }^{11}$ Ibid. 


\begin{tabular}{|c|c|c|}
\hline Ciri - Ciri & $\begin{array}{l}\text { 1. Bentuknya sesuai UU } \\
\text { Bentuk dari akta_notaris, akta } \\
\text { perkawinan, akta kelahiran dll } \\
\text { sudah ditentukan format dan } \\
\text { isinya oleh Undang-Undang. } \\
\text { Namun ada juga akta-akta } \\
\text { yang bersifat perjanjian antara } \\
\text { kedua belah pihak yang isinya } \\
\text { berdasarkan kesepakatan dari } \\
\text { kedua belah pihak sesuai } \\
\text { dengan azas kebebasan } \\
\text { berkontrak. } \\
\text { 2. Dibuat di hadapan pejabat } \\
\text { umum yg berwenang } \\
\text { 3. Kekuatan pembuktian yang } \\
\text { sempurna } \\
\text { 4. Kalau disangkal mengenai } \\
\text { kebenarannya, maka } \\
\text { penyangkal harus } \\
\text { membuktikan mengenai } \\
\text { ketidak benarannya. }\end{array}$ & $\begin{array}{l}\text { 1. Bentuknya yang } \\
\text { bebas } \\
\text { 2. Pembuatannya tidak } \\
\text { harus di hadapan } \\
\text { pejabat umum } \\
\text { 3.Tetap mempunyai } \\
\text { kekuatan pembuktian } \\
\text { selama tdk disangkal } \\
\text { oleh pembuatnya } \\
\text { 4. Dalam hal harus } \\
\text { dibuktikan, maka } \\
\text { pembuktian tersebut } \\
\text { harus dilengkapi juga } \\
\text { dengan saksi-saksi \& } \\
\text { bukti lainnya. Oleh } \\
\text { karena itu, biasanya } \\
\text { dalam akta di bawah } \\
\text { tangan, sebaiknya } \\
\text { dimasukkan } 2 \text { orang } \\
\text { saksi yang sudah } \\
\text { dewasa untuk } \\
\text { memperkuat } \\
\text { pembuktian. }\end{array}$ \\
\hline $\begin{array}{l}\text { Kekuatan } \\
\text { Pembuktian }\end{array}$ & $\begin{array}{l}\text { Akta autentik merupakan alat } \\
\text { pembuktian yang sempurna } \\
\text { bagi kedua belah pihak dan } \\
\text { ahli warisnya serta sekalian } \\
\text { orang yang mendapat hak } \\
\text { darinya tentang apa yang } \\
\text { dimuat dalam akta tersebut. } \\
\text { Akta autentik merupakan } \\
\text { bukti yang mengikat yang } \\
\text { berarti kebenaran dari hal-hal } \\
\text { yang tertulis dalam akta } \\
\text { tersebut harus diakui oleh } \\
\text { hakim, yatiu akta tersebut } \\
\text { dianggap sebagai benar } \\
\text { selama kebenarannya itu tidak } \\
\text { ada pihak lain yang dapat } \\
\text { membuktikan sebaliknya. }\end{array}$ & $\begin{array}{l}\text { Menurut Pasal } 1857 \\
\text { KHUPerdata, jika akta } \\
\text { dibawah tangan tanda } \\
\text { tangannya diakui oleh } \\
\text { orang terhadap siapa } \\
\text { tulisan itu hendak } \\
\text { dipakai, maka akta } \\
\text { tersebut dapat } \\
\text { merupakan alat } \\
\text { pembuktian yang } \\
\text { sempurna terhadap } \\
\text { orang yang } \\
\text { menandatangani serta } \\
\text { para ahli warisnya dan } \\
\text { orang-orang yang } \\
\text { mendapatkan hak } \\
\text { darinya. }\end{array}$ \\
\hline
\end{tabular}


Akta notaris sebagai akta autentik mempunyai kekuatan nilai pembuktian dalam 3 hal, yaitu sebagai berikut:

Pertama, kemampuan lahiriah (uitwendige bewijskracht) akta notaris merupakan kemampuan akta itu sendiri untuk membuktikan keabsahannya sebagai akta otentik (acta publica probant seseipsa) sebagaiakta otentik serta sesuai dengan aturan hukum yang sudah ditentukan mengenai syarat akta otentik, maka akta tersebut berlaku sebagai akta otentik sampai terbukti sebaliknya, artinya sampai ada yang membuktikan bahwa akta tersebut bukan akta otentik secaralahiriah, dalam hal ini beban pembuktian ada para pihak yang menyangkal keotentikan akta notaris, parameter untuk menentukan akta notaris sebagai akta autentik yaitu tanda tangan dari notaris yang bersangkutan, baik yang ada pada minuta dan salinan serta adanya awal akta (mulai dari judul) sampai dengan akhir akta. Nilai pembuktian akta notaris dari aspek lahiriah, akta tersebut harus dilihat apa adanya, bukan dilihat ada apa, secara lahiriah tidak perlu dipertentangkan dengan alat bukti yang lainnya, jika ada yang menilai bahwa suatu akta notaris tidak memenuhi syarat sebagai akte, maka yang bersangkutan wajib membuktikannya bahwa akta tersebut secara lahiriah bukan akta autentik.

Penyangkalan atau pengingkaran bahwa secara lahiriah akta notaris sebagai akta otentik, bukan akta otentik, maka penilaian pembuktiannya harus didasarkan kepada syarat-syarat akta notaris sebagai akta otentik.Pembuktian semacam ini harus dilakukan melalui upaya gugatan ke Pengadilan.Penggugat harus dapat membuktikan bahwa secara lahiriah akta yang menjadi obyek gugatan bukan akta notaris.

Kedua, kemampuan Formal (formele bewijskracht), akta notaris harus memberikan kepastian bahwa sesuatu kejadian dan fakta tersebut dalam akta betul-betul dilakukan oleh notaris atau diterangkan oleh pihakpihak yang menghadap pada saat yang tercantum dalam akta sesuai dengan prosedur yang sudah ditentukan dalam pembuatan akta, secara formal untuk membuktikan kebenaran dan kepastian tentang hari, tanggal, bulan, tahun, pukul (jam) menghadap dan pihak yang menghadap paraf dan tanda tangan para pihak/ penghadap, saksi dan notaris, serta membuktikan apa yang dilihat, disaksikan, didengar oleh notaris (pada akta pejabat/berita acara), dan mencatat keterangan atau pernyataan para pihak/penghadap.Jika aspek formal dipermasalahkan oleh para pihak, maka harus dibuktikan formalitas dari akta, yaitu harus dapat membuktikan ketidakbenaran hari, tanggal, bulan, tahun, pukul (jam) menghadap, membuktikan ketidakbenaran, para pihak yang menghadap, membuktikanapa yang dilihat, disaksikan, didengar oleh notaris, selain itu juga harus dapat membuktikan ketidakbenaran pernyataan atau keterangan para pihak yang diberikan / disampaikan dihadapan notaris dan ketidakbenaran tanda tangan para pihak, saksi dan 
notaris ataupun ada prosedur pembuatan akta yang tidak dilakukan, dalam hal para pihak yang mempermasalahan akta tersebut harus melakukan pembuktian terbalik, untuk menyangkal aspek formal dari akta notaris dan jika para pihak tidak mampu membuktikan ketidakbenaran tersebut, maka akta tersebut harus diterima oleh siapapun.Dalam pengingkaran atau penyangkalan atas aspek formal akta notaris, jika ada para pihak yang merasa dirugikan harus dilakukan gugatan ke Pengadilan umum dan penggugat harus dapat membuktikan bahwa ada aspek formal yang dilanggar atau tidak sesuai dalam akta yang bersangkutan atau yang bersangkutan tidak pernah merasa menghadap notaris pada hari, tanggal, bulan, tahun, pukul (jam) yang tersebut pada awal akta atau merasa tanda tangan yang ada dalam akta bukan tanda tangannya, jika hal tersebut terjadi yang bersangkutan atau penghadap tersebut berhak untuk menggugat notaris, dan penggugat harus dapat membuktikan ketidakbenaran aspek formal tersebut.

Ketiga, pembuktian materi (materiele bewijskracht), adalah tentang kepastian tentang materi suatu akta sangat penting, bahwa apa yang tersebut dalam akta merupakan pembuktian yang sah terhadap pihak-pihak yang membuat akta atau mereka yang mendapat hak dan berlaku untuk umum kecuali ada pembuktian sebaliknya (tegenbewijs), keterangan atau pernyataan para pihak harus dinilai benar, perkataan yang kemudian dituan gkan/dimuat dalam akta berlaku sebagai yang benar atau setiap orang yang datang menghadap notaris yang kemudian keterangannya dituangkan/dimuat dalam akta harus dinilai telah benar berkata demikian, jika ternyata pernyataan/keterangan para penghadap tersebut menjadi tidak benar, maka hal tersebut tanggung jawab para pihak sendiri, Notaris terlepas dari hal semacam itu, dengan demikian isi akta notaris mempunyai kepastian sebagai yang sebenarnya, menjadi bukti yang sah untuk/di antara para pihak dan para ahli waris serta para penerima hak. Apabila akan membuktikan aspek materil dari akta, maka yang bersangkutan harus dapat membuktikan bahwa notaris tidak menerangkan atau menyatakan yang sebenarnya dalam akta, atau para pihak yang telah benar berkata (dihadapan notaris) menjadi tidak benar berkata, dan harus dilakukan pembuktian terbalik untuk menyangkal aspek materil dari akta notaris. Laporan terhadap sebuah akta notaris, biasanya dilakukan oleh pihak yang tidak bertanggungjawab

\section{Kedudukan Hukum Kekuatan Akta Autentik}

Kedudukan hukum kekuatan akta autentik yang dibuat notaris terhadap pembuktian tidak pidana pemalsuan dapat dipahami dari aspek pembuktian lebih dulu. Artinya untuk mengkonstatir suatu peristiwa hukum maka peristiwa itu harus dibuktikan kebenarannya. Tujuan pembuktian 
adalah mencari atau menemukan kebenaran peristiwa yang digunakan sebagai dasar putusan hakim yang mempunyai akibat hukum. ${ }^{12}$

Menurut ahli pidana yaitu Erdianto, terhadap hasil laboratorium AJB dapat digolongkan sebagai yang dipalsukan, yaitu surat yang tergolong pemalsuan intelektuil sekaligus pemalsuan materil. Dikatakan pemalsuan intelektual karena isinya adalah tidak sesuai dengan kenyataannya, yang mana pelapor tidak pernah menjual tanah yang menjadi objek AJB. Dikatakan sebagai pemalsuan materil karena terhadap surat tersebut terdapat pemalsuan tandatangan sehingga seolah-olah benar surat itu asli dan tidak dipalsukan, sehingga perbuatan tersebut dapat digolongkan sebagai perbuatan membuat surat palsu sekaligus adanya perbuatan turut serta memalsukan surat terhadap akta otentik yaitu AJB.

Hal tersebut tunduk pada ketentuan Pasal 55 ayat (1) angka 1 Kitab Undang-Undang Hukum Pidana (yang selanjutnya disebut KUHP) menyebutkan:

(1) Dipidana sebagai pelaku tindak pidana:mereka yang melakukan, yang menyuruh melakukan, dan yang turut serta melakukan perbuatan; Adapun unsur-unsur pidana dari tindak pidana pemalsuan surat tersebut adalah: ${ }^{13}$

a. pada waktu memalsukan surat itu harus dengan maksud akan menggunakan atau menyuruh orang lain menggunakan surat itu seolah-olah asli dan tidak dipalsukan;

b. penggunaannya harus dapat mendatangkan kerugian. Kata“ dapat” maksudnya tidak perlu kerugian itu betul-betul ada, baru kemungkinan saja akan adanya kerugian itu sudah cukup. Yang diartikan kerugian di sini tidak saja hanya meliputi kerugian materiil, akan tetapi juga kerugian di lapangan masyarakat, kesusilaan, kehormatan, dan sebagainya (immaterial)

c. yang dihukum menurut pasal ini tidak saja yang memalsukan, tetapi juga sengaja menggunakan surat palsu. Sengaja maksudnya bahwa orang yang menggunakan itu harus mengetahui benar-benar bahwa surat yang ia gunakan itu palsu. Jika ia tidak tahu akan hal itu, ia tidak dihukum.

Kalau memahami deskripsi di atas, maka akta otentik yang dikeluarkan oleh notaris mempunyai kekuatan hukum yang mengandung kepastian hukum terhadap pembuktian tindak pidana pemalsuan. Dalam hal alat bukti, akta otentik yang dikeluarkan notaris ini berkedudukan sebagai alat bukti surat. Jika akta otentiknya dipalsukan, maka ia dapat menjadi

${ }^{12}$ Sudikno Mertokusumo, Op.Cit, hal. 165

${ }^{13}$ R. Soesilo, Op.Cit, ,hal. 196 
salah satu alat bukti yang bisa digunakan menjerat (mempertanggunjawabkan) pelakunya.

Jika notarisnya terlibat dalam hal terjadinya tindak pidana pemalsuan akta, maka notaris ini juga dapat dijerat dengan pertanggungjawaban sebagai pihak yang melakukan pelanggaran hukum.

\section{PENUTUP}

Kedudukan hukum akte otentik yang dbuat oleh notaris, bahwa akte otentik yang dibuat notaris secara yuridis adalah mengandung: pertama, kemampuan lahiriah (uitwendige bewijskracht) dimana akta notaris merupakan kemampuan akta itu sendiri untuk membuktikan keabsahannya sebagai akta otentik (acta publica probant seseipsa) serta sesuai dengan aturan hukum yang sudah ditentukan mengenai syarat akta otentik, sehingga akta tersebut berlaku sebagai akta otentik sampai terbukti sebaliknya, kedua, kemampuan Formal (formele bewijskracht), akta notaris harus memberikan kepastian bahwa sesuatu kejadian dan fakta tersebut dalam akta betul-betul dilakukan oleh notaris atau diterangkan oleh pihak-pihak yang menghadap pada saat yang tercantum dalam akta sesuai dengan prosedur yang sudah ditentukan dalam pembuatan akta, ketiga, akta yang dibuat oleh notaris mempunyai nilai kekuatan dalam beberapa hal, yakni pembuktian material (materiele bewijskracht), adalah tentang kepastian tentang materi suatu akta sangat penting, bahwa apa yang tersebut dalam akta merupakan pembuktian yang sah terhadap pihak-pihak yang membuat akta atau mereka yang mendapat hak dan berlaku untuk umum kecuali ada pembuktian sebaliknya (tegenbewijs). Dengan demikian, akta autentik merupakan bukti yang mengikat yang berarti kebenaran dari hal-hal yang tertulis dalam akta tersebut harus diakui oleh hakim, yatiu akta tersebut dianggap sebagai benar selama kebenarannya itu tidak ada pihak lain yang dapat membuktikan sebaliknya

\section{DAFTAR PUSTAKA}

\section{Buku:}

Anshori, 2009, Lembaga Kenotariatan Indonesia Perspektif Hukum dan Etika, Yogyakarta: UII Press.

Kartini Soedjendro, 2001, Perjanjian Peraihan Hak atas Tanah yang Berpotensi Konflik, Yogyakarta: Kanisius.

Nusyirwan, 2000, Membedah Profesi Notaris, Bandung: Universitas Padjadjaran .

R. Soesilo. 1991, Kitab Undang-undang Hukum Pidana (KUHP) Serta Komentar-Komentarnya Lengkap Pasal Demi Pasal, Bogor, Politeia. 
Soerjono Soekanto \& Sri Mamudji, 2003, Penelitian Hukum Normatf, Jakarta: Rajagrafindo Persada.

Grafika

, 1986, Pengantar Penelitian Hukum, Jakarta: Sinar

Sudikno Mertokusumo, 1998, Hukum Acara Perdata Indonesia, Edisi Keempat, Yogjakarta: Liberty.

Peraturan Perundang-undangan

Kitab Undang-undang Hukum Pidana (KUHP

Kitab Undang-Undang Hukum Perdata (KUHPdt)

Internet:

Arief Rachman, Akte Otentik Dalam Hukum Positip Indonesia, https://notarisarief.wordpress.com/2011/05/15/akta-otentik-dalamhukum-positif-indonesia/, akses 15 Oktober 2018. 